\title{
GAMBARAN KEMAMPUAN FUNGSIONAL PASIEN STROKE DI RSUD DR. SOEKARDJO TASIKMALAYA
}

\author{
Yanti Cahyati, S.Kep, Ners, M.Kep ${ }^{1}$ \\ ${ }^{1}$ Prodi D III Keperawatan Tasikmalaya \\ Jurusan Keperawatan Poltekkes Kemenkes Tasikmalaya
}

yantinaufal@gmail.com

\begin{abstract}
ABSTRAK
Pengkajian status kemampuan fungsional pasien stroke sangat penting dilakukan untuk memberikan intervensi sedini mungkin sehingga resiko kecacatan paska stroke dapat dihindari. Penelitian ini bertujuan melihat gambaran kemampuan fungsional pasien stroke. Jenis penelitian ini adalah penelitian deskriptif analitik dengan pendekatan cross sectional, dimana pengukuran variabelnya dilakukan satu kali. Variabelnya yaitu umur, jenis kelamin, jenis stroke, admission time, penyakit penyerta, frekuensi serangan, sisi hemiparese dan kemampuan fungsional. Peneliti melakukan penilaian status fungsional pasien stroke menggunakan Bartel Index pada saat hari ke-2 pasien di rawat di rumah sakit. Hasil penelitian menunjukkan pasien stroke ratarata berusia 54,5 tahun, jenis kelamin sebagian besar laki-laki $65.3 \%$. Responden sebagian besar didiagnosis stroke iskemik sebanyak $69,2 \%$, datang ke rumah sakit lebih dari 6 jam setelah serangan sebanyak $76,9 \%$. Sebagian besar responden $82.7 \%$ memiliki penyakit penyerta dan sebagian besar datang ke rumah sakit dengan serangan stroke pertama kali yaitu sebanyak $78.8 \%$. Sebagian besar responden mengalami hemiparese sisi sebelah kiri sebanyak $59.6 \%$. Sebagian besar responden terkategori dalam ketergantungan sebagian yaitu sebanyak $71.15 \%$. Saran penelitian ini adalah perlunya pengkajian mendalam tentang status fungsional pasien stroke sebagai upaya untuk mencegah ketergantungan total pasien paska stroke dan perlu penerapan intervensi yang tepat untuk mencegah terjadinya ketergatungan total.
\end{abstract}

Kata kunci : stroke, kemampuan fungsional

\begin{abstract}
An assessment of the status of functional abilities of stroke patients is very important for providing intervention as early as possible so that the risk of post-stroke disability can be avoided. This study aims to see an overview of the functional abilities of stroke patients. This type of research is analytical descriptive research with approach cross-sectional. The variables measured in this study were age, gender, type of stroke, admission time, comorbidities, a frequency of attacks, hemiparesis side, and functional ability. Researchers assessed the functional status of stroke patients by using Bartel Index on day 2 of patients in hospitalized. The results showed that stroke patients had an average age of 54.5 years with the majority of the sexes being men, which was $65.3 \%$. The majority of respondents were diagnosed with ischemic stroke as much as $69.2 \%$ and came to the hospital more than 6 hours after the attack as much as $76.9 \%$. Most of the respondents $(82.7 \%)$ had comorbidities and most came to the hospital with the first stroke, which was $78.8 \%$. Most of the respondents experienced hemiparesis on the left side as much as $59.6 \%$. Most of the respondents are categorized as partially dependent, which is $71.15 \%$. Suggestions from this study are the need for an in-depth study of the functional status of stroke patients in an effort to prevent total dependence on post-stroke patients and the need to implement appropriate interventions to prevent the occurrence of total dependence on stroke patients.
\end{abstract}

Keywords: stroke, functional ability 


\section{PENDAHULUAN}

Stroke adalah suatu kondisi yang digunakan untuk menjelaskan perubahan neurologik yang disebabkan oleh gangguan dalam sirkulasi darah ke bagian otak. Secara umum hal ini dapat menyebabkan gangguan neurologik fokal yang dapat timbul sekunder dari suatu proses patologi pada pembuluh darah serebral. Stroke merupakan penyakit gangguan fungsional otak akut fokal maupun global akibat terhambatnya aliran darah ke otak karena perdarahan (hemoragik) ataupun sumbatan (stroke iskemik). Gejala dan tanda yang timbul sesuai bagian otak yang terkena, yang dapat sembuh sempurna, sembuh dengan cacat, atau atau meninggal (Junaidi, 2011)

Berdasarkan laporan American Heart Association (AHA), sekitar 700.000 orang di Amerika Serikat terserang stroke setiap tahunnya. Saat ini ada 4 juta orang di Amerika Serikat yang hidup dengan keterbatasan fisik akibat stroke, dan 15$30 \%$ diantaranya menderita cacat menetap (Wirasakti, 2013). Badan Penelitian dan Pengembangan Kesehatan (2013) menyampaikan bahwa data revalensi stroke di Indonesia berdasarkan diagnosis tenaga kesehatan sebesar 7 per mil dan yang terdiagnosis tenaga kesehatan atau gejala sebesar 12,1 per mil Sejalan dengan data tersebut. Sesuai studi pendahuluan di Rumah Sakit Umum Dr. Soekardjo Tasikmalaya, kasus stroke menempati urutan pertama kasus yang paling banyak ditemukan di ruang perawatan saraf. Angka kejadian stroke tersebut setiap tahunnya selalu mengalami peningkatan. Selama tahun 2016 terdapat 652 kasus stroke yang di rawat di Ruang V RSUD dr. Soekardjo Tasikmalaya.

Stroke merupakan penyebab kecacatan yang utama. Laporan World Stroke Organization (WSO) (2009) menujukkan bahwa stroke adalah penyebab utama hilangnya hari kerja dan kualitas hidup yang buruk. Kecacatan akibat stroke tidak hanya berdampak bagi para penyandangnya, namun juga bagi para anggota keluarganya. Beban ekonomi yang ditimbulkan akibat stroke juga sedemikian beratnya. Stroke merupakan penyebab utama gangguan fungsional, dimana $20 \%$ penderita yang bertahan hidup masih membutuhkan perawatan di institusi kesehatan setelah 3 bulan dan 15-30\% penderitanya mengalami cacat permanen (Yenni, 2011).

Hasil penelitian Fandri (2014) menunjukan mayoritas pasien stroke memiliki status fungsional ketidakmampuan sangat parah. Defisit motorik berupa hemiparese atau hemiplegia yang dialami oleh pasien stroke dapat mengakibatkan kondisi imobilitas. Kondisi ini dapat menyebabkan terjadinya penurunan kekuatan otot yang dapat mengakibatkan ketidakmampuan pada otot ekstremitas secara umum, penurunan fleksibilitas dan kekakuan sendi yang dapat mengakibatkan kontraktur sehingga pada akhirnya pasien akan mengalami keterbatasan/disability terutama dalam melakukan activities of daily living (ADL) (Lewis, 2007).

Status fungsional adalah kemampuan individu untuk melakukan kegiatan seharihari yang normal yang diperlukan untuk memenuhi kebutuhan dasar, memenuhi status peran, dan menjaga kesehatan dan kesejahteraan. Status fungsional tidak hanya terkait kegiatan fisik tetapi juga terkait psikologis, sosial, dan spiritual. Status fungsional dapat dipengaruhi oleh gangguan biologis atau fisiologis, gejala, suasana hati, dan faktor-faktor lain. Pada pasien stroke akibat perubahan fisiologisnya akan mengalami hambatan dalam melakukan aktifitas sehari-hari, hal ini akan menyebabkan adanya perubahan dalam status fungsionalnya.

Saltzman dalam Ropyanto (2011) menjelaskan status fungsional dapat dikaji melalui pengkajian fungsional dengan menggunakan alat ukur untuk mendapatkan gambaran indikasi keparahan suatu penyakit, mengukur kemampuan, dan kebutuhan individu terhadap perawatan, memonitor perubahan sepanjang waktu, serta untuk pantauan pemeliharaan. 
Pengukuran yang dapat digunakan sebagai alat ukur status fungsional yaitu Indeks Katz, Indeks Kenny Self Care, The Index of Independence in Activities of Daily Living (IADL), Functional Independent Meassure (FIM), Indeks Barthel.

Status fungsional pada pasien stroke dapat diukur salah satunya adalah dengan menggunakan Indeks Barthel sebagai istrumen untuk mengukur kategori ketergantungan kemampuan fungsi yang dialami. Pasien stroke yang mengalami kelumpuhan pada salah satu atau kedua anggota ekstremitas atas (tangan) pasti mengalami kesulitan dalam hal kebutuhan fisiologis, makan. Gangguan makan pada pasien stroke tidak hanya dapat berakibat pada sistem pencernaan dan energinya tetapi dapat berakibat juga dengan penurunan konsentrasi atau penurunan kognitif pasien.

Meningkatnya angka kejaadian stroke akan memberikan dampak yang buruk bagi penderita stroke dan keluarganya. Luaran dari pasien stroke adalah bisa berupa angka kematian atau status fungsional. Melakukan pengukuran status fungsional merupakan hal penting yang harus dikaji terhadap pasien stroke sehingga memberikan gambaran dalam meberikan intervensi. Oleh karena itu peneliti tertarik untuk melakukan penelitian tentang gambaran kemampuan fungsional pasien stroke di RSUD Dr. Soekardjo Tasikmalaya.

\section{METODE PENELITIAN}

Desain penelitian yang digunakan adalah deskriptif analitik dengan pendekatan cross sectional, dimana pengukuran variabelvariabelnya dilakukan hanya satu kali. Variabel yang akan diukur dalam penelitian ini adalah umur, jenis kelamin, jenis stroke, admission time, penyakit penyerta, frekuensi serangan, sisi hemiparese dan kemampuan fungsional.

Populasi dalam penelitian ini adalah semua pasien stroke yang di rawat di Ruang $\mathrm{V}$ RSUD Kota Tasikmalaya pada saat penelitian dilakukan. Rata-rata jumlah pasien stroke yang di rawat di Ruang V RSUD Kota
Tasikmalaya setiap bulannya adalah 60 orang. Pengambilan sampel dilakukan dengan consecutive sampling, dimana semua subjek penelitian yang datang dan memenuhi criteria pemilihan dimasukkan ke penelitian sampai batas waktuya terpenuhi. Kriteria inklusi sampel penelitian ini adalah :

a. Pasien Stroke yang dirawat di Ruang V RSUD Kota Tasikmalaya

b. Kesadaran compos mentis dan mampu berkomunikasi secara wajar

c. Hemodinamik stabil : tekanan darah, pernafasan, suhu dan nadi

d. Bisa membaca dan menulis

e. Bersedia menjadi responden dan menandatangani informed consent.

Sedangkan kriteria eksklusi dalam penelitian ini antara lain:

a. Pasien stroke yang mengalami afasia motorik, sensorik maupun global

b. Pasien stroke dalam fase progresif (stroke in evolution)

Berdasarkan kriteria tadi didapatkan jumlah sampel dalam penelitian ini sebanyak 52 orang.

\section{HASIL PENELITIAN}

Hasil analisis univariat dapat dilihat pada tabel berikut ini :

Tabel 1

Distribusi Responden Berdasarkan
Usia

\begin{tabular}{ccc}
\hline Mean & SD & Min-Maks \\
\hline 54.52 & 7.05 & $36-73$ \\
\hline
\end{tabular}

Berdasarkan tabeL 1 di atas dapat dilihat bahwa rata-rata usia responden adalah 54.52 tahun. 
Tabel 2

\section{Distribusi Responden Berdasarkan Jenis Kelamin, Admission Time, penyakit penyerta, frekuensi serangan dan Sisi Hemiparese}

\begin{tabular}{lcc}
\hline \multicolumn{1}{c}{ VARIABEL } & JUMLAH & $\%$ \\
\hline Jenis Kelamin & & \\
\hline 1. Laki-laki & 34 & $\mathbf{6 5 , 3}$ \\
\hline 2. Perempuan & 18 & $\mathbf{3 4 , 6}$ \\
\hline Jenis Stroke & & \\
\hline 1. Iskemik & 36 & 69,2 \\
\hline 2. Hemoragik & 16 & 30,7 \\
\hline Admision Time & & \\
\hline 1. Kurang dari 6 jam & 12 & 23,1 \\
\hline 2. Lebih dari 6 jam & 40 & 76.9 \\
\hline Penyakit Penyerta & & \\
\hline 1. Ada & 43 & 82.7 \\
\hline 2. Tidak Ada & 9 & 17.3 \\
\hline $\begin{array}{l}\text { Frekuensi } \\
\text { Serangan }\end{array}$ & & \\
\hline 1. Pertama & 41 & 78.8 \\
\hline 2. Ulangan & 11 & 21.2 \\
\hline Sisi Hemiparese & & \\
\hline 1. Kiri & 31 & 59.6 \\
\hline 2. Kanan & 21 & 40.4 \\
\hline \multicolumn{1}{c}{ JUMLAH } & $\mathbf{5 2}$ & $\mathbf{1 0 0}$ \\
\hline \multicolumn{2}{l}{} \\
\hline
\end{tabular}

Tabel 3

\section{Kemampuan Fungsional Responden}

\begin{tabular}{lcc}
\hline \multicolumn{1}{c}{ VARIABEL } & JUMLAH & $\%$ \\
\hline Mandiri & 15 & $\mathbf{2 8 , 8 5}$ \\
\hline $\begin{array}{l}\text { Ketergantung } \\
\text { sebagian }\end{array}$ & 37 & $\mathbf{7 1 , 1 5}$ \\
\hline $\begin{array}{l}\text { Ketergantungan } \\
\text { total }\end{array}$ & 0 & $\mathbf{0}$ \\
\hline \multicolumn{1}{c}{ JUMLAH } & 53 & $\mathbf{1 0 0}$ \\
\hline
\end{tabular}

Berdasarkan data pada tabel 2 di atas dapat dilihat bahwa sebagian besar responden berjenis kelamin laki-laki $65,3 \%$, sebagian besar responden menderita stroke iskemik $69,2 \%$, waktu datang ke Rumah sakit sebagian besar lebih dari 6 jam 76.9\%. Sebagian besar responden memiliki penyakkit penyerta $82.7 \%$, sebagian besar responden merupakan pasien pertama kali serangan $78.8 \%$ dan sebagian besar pasien mengalami hemiparese pada sisi kiri 59,6\%.

Berdasarkan data pada table 3 di atas dapat dilihat bahwa sebagian besar responden memiliki kemampuan fungsional kategori ketergantung sebagian $71,15 \%$.

\section{PEMBAHASAN}

\section{Usia}

Hasil penelitian menunjukkan bahwa ratarata usia responden adalah 54.52 tahun. Usia merupakan non modificable factor untuk terjadinya stroke. Usia merupakan salah satu faktor yang meningkatkan insiden kejadian stroke (Black \& Hawk, 2010). Namun demikian pada kondisi sekarang ini stroke dapat terjadi pada usia produktif. Hal ini salah satunya disebabkan karena gaya hidup yang tidak sehat, seperti kebiasaan merokok, minum alkohol, diabetes melitus, dan makanan tinggi lemak dan kolesterol. Kesemuanya itu dapat menyebabkan sumbatan pada pembuluh darah otak sehingga menyebabkan berkurangnya suplai oksigen dalam darah ke semua jaringan termasuk otak yang dapat berakibat terjadinya kematian jaringan pada otak.Umur merupakan salah satu resiko utama stroke, resiko stroke meningkat hampir dua kali lipat setelah umur 55 tahun. Hal ini disebabkan karena melemahnya fungsi tubuh secara menyeluruh terutama terkait dengan fleksibilitas pembuluh darah (Fandri, 2014).

\section{Jenis Kelamin}

Hasil penelitian menunjukkan bahwa sebagian sebagian besar responden berjenis kelamin laki-laki 65,3\%. Menurut Balck \& Hawk (2010), angka kejadian stroke pada laki-laki lebih tinggi dibandingkan pada wanita. Beberapa penelitian menunjukkan analisis bahwa lakilaki yang mengalami stroke memiliki angka mortalitas lebih rendah dibandingkan dengan wanita. Oleh karena itu angka kejadian penyakit stroke pada laki-laki selalu mengalami peningkatan setiap tahunnya. Sedangkan pada wanita angka mortalitas akibat stroke cenderung lebih tinggi, sehingga dalam hal insiden angka 
kejadian stroke pada wanita lebih rendah dibandingkan dengan laki-laki. Sejalan dengan pendapatnya Burhanudin dan Jumriani (2012) yang menyatakan bahwa pria memiliki resiko lebih besar terkena stroke pada usia dewasa awal dibandingkan dengan wanita, namun walaupun pria lebih rawan daripada wanita pada usia yang lebih muda tetapi wanita akan menyusul setelah mereka mencapai menopause. Perbedaan ini terjadi karena pada

perempuan, ketika memasuki masa menopause(45-55 tahun) resiko stroke meningkat karenaestrogen yang semula berperan sebagaipelindung mengalami penurunan. Perempuanjuga memiliki resiko yang cukup tinggi terhadapstroke jika mereka merupakan pengguna pil $\mathrm{KB}$,menjalani terapi sulih hormon, serta kehamilandan persalinan. Resiko stroke relatif tinggi 6 minggu pasca persalinan. Perubahan hormone reproduksi yang terjadi pada wanita merupakan faktor pemicunya (Lingga, 2013).

\section{Jenis Stroke}

Sebagain besar responden stroke iskemik $(69,2 \%)$. Stroke iskemik angka kejadianya lebih tinggi dibandingkan dengan stroke hemoragik, hal ini berkaitan degan kejadian meningkatnya aterosklerosis vasculer yang menyebabkan terjadinya sumbatan pada pembuluh darah, sumbatan inilah yang kemudian memicu terjadinya stroke (Lipska, et. All, 2007). Stroke iskemik terjadi akibat gangguan sirkulasi dari pembuluh darah otak akibat obstruksi dari aliran pembuluh darah. Obstruksi dapat disebabkan oleh bekuan darah (thrombus) yang terbentuk di dalam suatu pembuluh darah otak atau pembuluh darah organ distal. Pada thrombus vacsula distal, bekuan dapat terlepas atau mungkin terbentuk dalam suatu organ seperti jantung dan kemudian dibawa melalui sistem arteri ke otak sebagai embolus (Price \& Wilson, 2007).

Price \& Wilson (2007) menyatakan bahwa proporsi stroke iskemik lebih besar daripada stroke hemoragik. Stroke iskemik lebih sering berhubungan dengan gaya hidup masyarakat yang tidak sehat, seperti masyarakat yang menyukai makanan cepat saji serta berkolesterol tinggi, kebiasaan merokok dan konsumsi alkohol yang menyebabkan penimbunan plak, sehingga lama kelamaan dapat menyumbat pembuluh darah dan aliran darah ke otak pun tersumbat (Rachmawati, 2013).

\section{Admission Time}

Hasil penelitian menunjukkan bahwa sebagian besar responden datang ke Rumah Sakit lebih dari 6 jam setelah serangan yaitu sebanyak $76.9 \%$.Studi yang dilaksanakan oleh Broadley \& Thompson (2003) terhadap 284 pasien dirawat di rumah sakit dengan stroke, $35 \%$ dirawat dalam waktu antara 4-6 jam dari onset gejala, dan $28 \%$ dalam waktu dua jam, sedangkan sisanya > 6jam. Pasien-pasien dengan stroke berat dan mengalami penurunan kesadaran serta tinggal di wilayah dengan akses yang mudah ke rumah sakit memiliki kecenderungan untuk lebih cepat melakukan perawatan di rumah sakit. Waktu 3-6 jam (golden period) merupakan waktu yang penting untuk penanganan stroke, karena dalam waktu ini terbukti efektif dalam pemulihan fungsi otak dan memperkecil kerusakan neuron setelah stroke iskemik. Terapi yang terbukti efektif dalam memulihkan fungsi otak dan memperkecil kerusakan neuron setelah stroke iskemik salah satunya adalah pemberian terapi aktivator plasminogen jaringan (TPA) yang diberikan dalam waktu 3 jam (Lemone \& Burke, 2004. ; Price \& Wilson, 2006. ; Smeltzer \& Bare, 2008). Jika dalam waktu kurang dari 6 jam pasien datang ke rumah sakit dan mendapatkan terapi TPA kemungkinan daerah disekitar infark yang mengalami iskemik masih dapat dipertahankan. Penelitian menunjukkan bahwa inisiasi pemberian TPA (3-6 jam) dapat menurunkan ukuran/derajat stroke dan meningkatkan kemampuan fungsional dalam 3 bulan (Smeltzer \& Bare, 2008).

\section{Penyakit Penyerta}

Hasil penelitian menunjukkan bahwa sebagain besar responden memiliki penyakit penyertaseperti hipertensi, hiperkholesterol dan Diabetes Mellitus (DM) 
yaitu sebanyak $82.7 \%$. Kondisi hipertensi ini beresiko menyebabkan pecahnya pembuluh darah yang pada akhirnya dapat menyebabkan stroke. Menurut (Feigin, 2006) makin tinggi tekanan darah makin tinggi kemungkinan terjadinya stroke, baik non hemoragik maupun hemoragik. Meningkatnya kadar kolesterol dalam darah terutama LDL merupakan faktor resiko untuk terjadinya arterosklerosis. Pada pasien diabetes, kadar gula darah yang tinggi pada saat stroke akan memperbesar kemungkinan meluasnya infark karena terbentuknya asam laktat akibat metabolisme glukosa secara anaerob yang merusak jaringan otak. Pasien dengan penyakit penyerta akan memberikan dampak yang kurang baik terhadap proses penyebuhan stroke, karena pengobatan dan perawatan tidak terfokus dalam menangani stroke tetapi juga dalam menangani penyakit penyerta.

\section{Frekuensi serangan}

Hasil penelitian menunjukkan bahwa sebagian besar responden merupakan kasus stroke dengan serangan pertama kali yaitu sebanyak $78.8 \%$. Hasil penelitian ini sejalan dengan survei statistik yang dilakukan di Amerika Serikat yang mengungkapkan bahwa tiap tahun kurang lebih 700 ribu orang di Amerika mengalami stroke. Dari jumlah itu, sekitar 500 ribu merupakan serangan pertama dan 200 ribu merupakan serangan stroke berulang (U.S. Centers for Disease Controland Prevention dan the HeartDisease and Stroke Statistics, 2007). Stroke susulan dapat terjadi setelah stroke pertama, beberapa bulan atau beberapa tahun kemudian (Lingga, 2013).

Stroke susulan umumnya disebabkan faktor yang sama. Namun tidak tertutup kemungkinan terjadi karena faktor penyebab yang berbeda. Jenis stroke pertama dan stroke yang selanjutnya terjadi dapat sama atau berbeda bergantung faktor risiko yang berpotensi menyebabkan kerusakan pada otak. Bisa terjadi stroke yang pertama merupakan stroke iskemik, dan stroke susulan merupakan stroke hemoragik atau sebaliknya (Lingga, 2013).Serangan stroke ulang berkisar antara 30\% - 43\% dalam kurun waktu 5 tahun. Setelah serangan otak sepintas, $20 \%$ pasien mengalami stroke dalam waktu 90 hari, dan $50 \%$ diantaranya mengalami serangan stroke ulang dalam waktu 24 - 72 jam. Tekanan darah yang tinggi (tekanan darah sistolik > $140 \mathrm{mmHg}$ dan tekanan darah diastolik > $90 \mathrm{mmHg}$ ) akan meningkatkan risiko terjadinya stroke ulang (Purtierplacenta, 2012).

Perjalanan penyakit stroke beragam, penderita tersebut dapat pulih sempurna, ada pula yang sembuh dengan cacat ringan, sedang sampai berat. Pada kasus berat dapat terjadi kematian, pada kasus yang bertahan hidup beberapa kemungkinan terjadi stroke berulang, dementia, dan depresi. Stroke merupakan penyakit yang paling banyak menyebabkan cacat pada usia di atas 45 tahun (Siswanto, 2005). Stroke ulang biasanya akan memberikan dampak yang lebih buruk terhadap kemampuang fungsional pasien.

\section{Sisi Hemiparese}

Sebagian besar responden mengalami hemiparese pada sisi kiri yaitu sebanyak $59,6 \%$. Hemiparesis terjadi karena adanya kerusakan pada salah satu sisi yang bersifat kontralateral, yakni jika kelemahan otot terjadi pada sisi tubuh yang berlawanan dengan sisi otak yang mengalami kerusakan, misalnya jika terjadi kerusakan pada otak bagian kanan maka hemiparesis akan terjadi pada bagian tubuh sebelah kiri, atau pun sebaliknya. Hemiparesis juga dapat terjadi pada sisi otak yang sama.Akibat hemiparese tersebut, pasien akan mengalami kesulitan dalam beraktivitas sehari-hari, misalnya berdiri, berjalan, makan, berbicara, berpakaian, bahkan saat menggunakan toilet.

\section{Kemampuan Fungsional}

Hasil penelitian mennunjukkan bahwa sebagian besar pasien stroke di rawat di RS pada hari ke-2 dalam status fungsional ketergantungan sebagian $(71.15 \%)$. Pasien stroke akan mengalami kelumpuhan motorik yang akan menyebabkan pasien menngalami hambatan dalam melakukan 
gerakan, terutama gerakan tangan dan kaki. Hal ini akan menyebabkan pasien mengalami ketergantungan dalam melakukan aktifitas sehari-hari. Pada pasien dengan penurunan tingkat kesaradan akan menyebabkan pasien mengalami ketergantungan total dalam memenuhi kebutuhan sehari-hati. Stroke merupakan penyebab utama gangguan fungsional, dimana $20 \%$ penderita stroke yang bertaha hidup masih membutuhkan perawatan selama 3 bulan dan $15-30 \%$ nya menderita cacat permanen. Penurunan kemampuan dapat terjadi karena penurunan kesadaran atau karena daearh terentu pada otak yang mengontrol pergerakan tidak tidak berfungsi sebagai akibat dari tersumbatnya suplay darah ke otak. Pemulihan neurologis terjadi setelah awal stroke, sedangkan pemulihan fungsional masih dapat terus terjadi sampai batas- batas tertentu dalam $3-6$ bulan pertama setelah stroke (Wirawan, 2009).

\section{SIMPULAN DAN SARAN}

\section{Kesimpulan}

Berdasarkan hasil penelitian ini pasien stroke rata-rata berusia 54,5 tahun dengan jenis kelamin sebagian besar laki-laki yaitu sebanyak $65.3 \%$. Responden sebagian besar di diagnosa stroke iskemik sebanyak $69,2 \%$ dan datang ke rumah sakit lebih dari 6 jam setelah serangan sebanyak $76,9 \%$. Sebagian besar responden $82.7 \%$ memiliki penyakit penyerta dan sebagian besar datang ke rumah sakit dengan serangan stroke pertama kali yaitu sebanyak $78.8 \%$. Sebagian besar responden memiliki hemiparese pada sisi sebelah kiri yaitu sebanyak 59.6\%. Sebagian besar responden terkategori dalam ketergantungan sebagian yaitu sebanyak $71.15 \%$.

\section{Saran}

Berdasarkan hasil penelitian peneliti merekomendasikan pentingnya pengkajian mendalam tentang kemampuan fungsional pasien stroke saat awal masuk rumah sakit dan saat pasien keluar dari rumah sakit setelah di rawat. Hasil pengkajian tersebut dijadikan dasar dalam memberikan intervensi yang tepat sehingga pasien dapat terhindar dari ketergantungan total paska stroke.

\section{UCAPAN TERIMAKASIH}

Ucapan terima kasih dan penghargaan yang setinggi-tingginya penulis sampaikan kepada :

1. Seluruh responden di Ruang V RSUD Dr. Soekardjo Tasikmalaya

2. Direktur Poltekkes kemenkes tasikmalaya

3. Ketua Jurusan Keperawatan Poltekkes Kemenkes Tasikmalaya

4. Ketua Program Studi D III Keperawatan Poltekkes Kemenkes Tasikmalaya

5. Kaunit Penelitian, reviewer dan seluruh jajaran redaksi

6. Semua tim yang terlibat dalam kegiatan penelitian ini.

\section{DAFTAR PUSTAKA}

Purwasih, E. O., Permana, I., \& Primanda, Y. (2017). Relaksasi Benson Dan Terapi Murottal Surat Ar-Rahmaan Menurunkan Kadar Glukosa Darah Puasa Pada Penderita Diabetes Melitus Tipe 2 Di Kecamatan Maos. Jurnal IImiah Kesehatan Keperawatan, 13(2).

American Heart association. (2010). Heart deases and stroke statistic: our guide to current statistics and the suplement to our heart and stroke fact- 2010 update.http://www.americanheart.org. Diakses pada tanggal 14 Maret 2011.

Black,J.M., \& Hawks,J.H., (2009) Medical surgical nursing clinical management for positive outcomes, $8^{\text {th }}$ Edition. St Louis Missouri : Elsevier Saunders.

Burhanuddin, M., Wahiduddin.,\& Jumriani. (2012). Faktor resiko kejadian strokepada dewasa awal (18-40) di Kota Makassar tahun 2010-2012. Diperolehtanggal 5 Juli 2014 darihttp://repository.unhas.ac.id 
Fandri, S. Utomo, W. Dewi, AP. (2014) Perbedaan Status FUngsional Pasien Stroke Saat Masuk dan Keluar RSUD Arifin Ahmad. Riau

Hahn K., and Kim S. 2006. Effect of progressive muscle relaxation technique on hypertension. American Journal Hypertension, 6(2), 335-339 Hoelscher, T. J., \& Lichstein, K.L. Home Relaxation Treatment: Objective Assesment and Complience Induction. Journal of Consulting and Clinical Psychology.

Huda, N. Yatine, R.Z. ((2013). HUbungan Status Fungsional terhadap Tingkat Depresi pada Pasien Stroke.

Junaidi, I. 2011. Stroke waspadai ancamannya. Andi. Yogjakarta

Lingga, L. (2013). All about stroke: Hidupsebelum dan pasca stroke. Jakarta:

Elex

Media Komputindo

Kristiyawati, S.P. , Irawaty, D., Hariyati, Rr.T.S.2009. Faktor Resiko yang Berhubungan dengan Kejadian Stroke di RS Panti Wilasa Citarum Semarang. Jurnal Keperawatan dan Kebidanan (JJIK), Volume I (1), 30. Semarang. STIKES Telogorejo

Kozier, B., et al. (2008). Kozier and Erb'sFundamentals of nursing, concept, process and practic, eighth edtion. New Jersey : Pearson Education.

Kozier,B. et al. (2004). Techniques in clinical nursing $5^{\text {th }}$ edition. Canada : Cummings Publishing Company.

Lemone,P., \& Burke,K. (2004). Medical Surgical Nursing Critical Thinking in Client Care. Third Edition. New Jersey : Pearson Education.

Lewis (2007). Medical surgical nursing : assessment \& management of clinical problem. $7^{\text {th }}$ edition. St.Louis :
Missouri.Mosby-Year Book, Inc

Lewis, G. N., \& Byblow, W. D. (2004). Neurophysiological and behavioural adaptations to a bilateral training intervention in individuals following stroke. Clinical Rehabilitation, 18(1), 48-59.

Polit, D.F., \& Beck, C.T. (2008). Essensials of nursing research: methods, appraisal and utilization (6 $\left.6^{\text {th }} \mathrm{Ed}\right)$. Philadelphia: Lippincott Williams \& Walkins.

Potter, A.P., \& Perry, A. (2006). Fundamental of nursing. $4^{\text {th }}$ edition. St.Louis Missouri:Mosby-Year Book, Inc.

Price, S.A., \& Wilson, L.M. (2006) Patofisiologi konsep klinis proses penyakit Edisi 6. EGC. Jakarta.

Rachmawati, F. 2013. Gambaran Stattus Fungsional Pasien Stroke Saat Masuk Ruang Rawat Inap RSUD Achmad Pekanbaru. Skripsi PSIK UNRI.

R.A. Nably. 2012. Deteksi Dini Gejala dan Pengobatan Stroke. Nuha Medika. Yogyakarta.

Rekam Medis RSUD Kota Tasikmalaya, (2012). Laporan kasus rawat inap dan rawat jalan RSUD Kota Tasikmalaya.

Riskesdas. 2013. Badan Penelitian dan Pengembangan Kesehatan Kemenkes RI Tahun 2013

Rolf, G. Jacob., Alvin, et al. 1992. Relaxation Therapy for Hypertension: Setting - Specific Effect. http://www.pubmedcentral.nih.gov

Sastroasmoro, S., \& Ismael, S. (2010). Dasar-dasar metodologi penelitian klinis. Edisi ke-3. Jakarta : Sagung Seto.

Sarikaya, P. M., Incel, N. A., Yilmaz, A., Cimen, O. B., \& Sahin, G. (2017). 
Effect of Hand Dominance on

Functional Status and Recovery of Hand in Stroke Patients. Science, 6(3), 39-45.

Smeltzer, S.C., Bare, B.G., Hinkle, J.L. \& Cheever, K.H. (2008) Brunner \& Suddarth's Textbook of medicalsurgical nursing. 11th Edition. Philadelphia : Lippincott William \& Wilkins.

Sugiyono. (2010). Metode penelitian kuantitatif, kualitatif dan $R$ \& $D$. Bandung : Alfabeta. 